\section{A CASE STUDY ON GOAL ORIENTATIONS FOR TEACHING}

\begin{abstract}
The present research aimed to explore actions, views, and emotions in relation to teachers' goal orientations and the reflection of goal orientations on their teaching practices. The study also aimed to compare whether there were differences among teachers' practices based on their goal orientations. A case study design was adopted and 10 teachers who taught in different schools and school levels participated in the study. Those 10 teachers were grouped into two goal orientations; those with Learning-Mastery-Goal-Orientations (L-M-GO) and those with Learning-MasteryPerformance-Goal-Orientations (L-M-P-GO). A questionnaire and semi-structured interviews were held with teachers and the collected data were analysed using qualitative techniques. The results suggested while all teachers-regardless of their goal orientations- defined themselves as individuals who made efforts to learn, those with L-M-P-GO orientations experienced negative emotions and ideas in their learning journeys. Moreover, all teachers reported that there were certain cases where they avoided work. There were differences between teachers' classroom practices and ideas based on their goal orientations.
\end{abstract}

\section{KEYWORDS}

Case study, classroom practices, coding, qualitative data analyses, teachers' goal orientations

\section{HOW TO CITE}

Yıldızlı H. (2021) 'A Case Study on Goal Orientations for Teaching', Journal on Efficiency and Responsibility in Education and Science, vol. 14, no. 1, pp. 9-27. http://dx.doi.org/10.7160/ eriesj.2021.140102

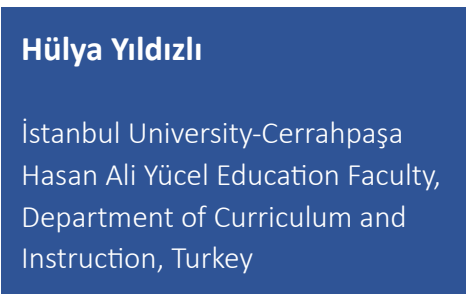

hulyayildizli@istanbul.edu.tr

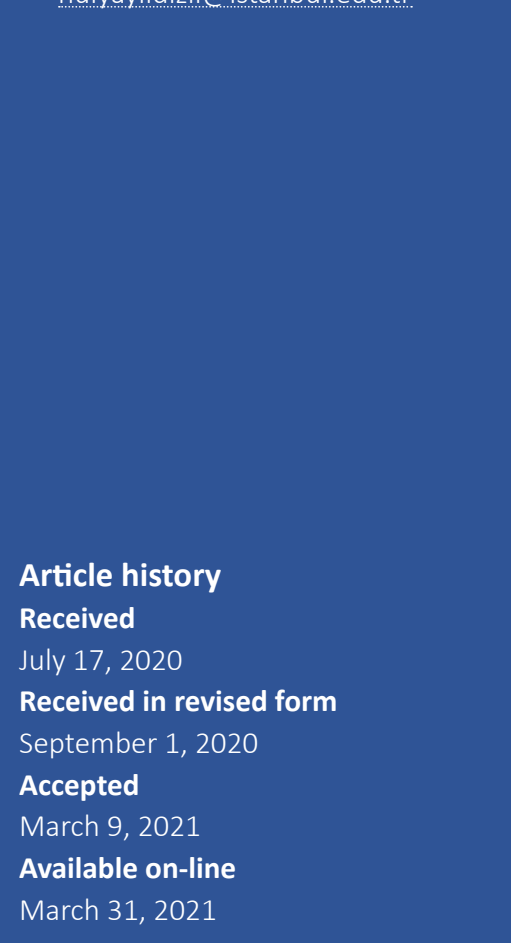

Highlights

- Teachers who have Learning-Mastery-Performance-Goal-Orientations experienced negative emotions and ideas in their learning journeys.

- Regardless of their goal orientations, success was considered as a source of motivation for all teachers and they wanted others to know about their successes.

- Regardless of their goal orientations, teachers were found to group students based on their levels and taught their lessons at the level of an average student.

- Teachers with Learning-Mastery-Performance-Goal-Orientations were found to support in-class competition.

\section{INTRODUCTION}

Researches on goal orientations, which are important for both students and teachers during teaching/learning processes, advocate that individuals can possess multiple goal orientations simultaneously. For example, qualitative research studies (Levy, Kaplan, and Patrick, 2004; Y1ldıl1, 2020) suggested that individuals strongly possess one of goal orientations and other goal orientations less strongly. Goal orientations they possessed can differ depending on the circumstances and personality traits. The analysis of related frameworks (in relation to goal orientations in the literature) suggested that the detrimental effects of the performance-approach should be re-examined since it was later split into two sub-categories; performance-approach and performance-avoidance (Pintrich, 2000). Additionally, the view that performance-approach can be interrelated with mastery-approach resulted in the development of perspectives advocating multi-goal theses by researchers (Barron and Harackiewicz, 2001; Linnenbrink, 2005). If researchers are to study teachers' goal orientations and their practice in classes and schools in relation to those orientations then investigating the interaction between teachers, students, classes, and schools becomes important. The present study aimed to reveal the similarities and differences among teachers' (those with different goal orientations) classroom and school practices as well as their emotions and views on those practices. Classroom and school practices were evaluated based on the dynamics of goal orientations towards teaching.

\section{Theoretical Framework}

Many studies have been conducted on students' goal 
orientations. More recently, however, attention has started to shift onto teachers' goal orientations. In fact, this topic, in the international literature, has been introduced as a factor that has been studied in the last 15-20 years and found to affect motivational beliefs in relation to the teaching profession. Goal orientations relate to the goals individuals set for themselves and affect the actions they take in relation to those goals. Goal orientation is a dimension that also relates to individuals' attitudes towards tasks, completing the tasks, and evaluating performance in a given task. It is a motivational belief that questions why individuals want to be successful, why they want to complete a given task, and how they decide on the criteria of success whilst completing the task (Pintrich, 2000). A number of different categorizations are available in achievement goal theory. For example; (1) learning goal and performance goal (Dweck, 1986), (2) task involvement and ego involvement (Nicholls, 1984), (3) mastery goal and performance goal (Ames, 1992), (4) learning-approach, performance-approach, and performance-avoidance (Elliot and Harackiewicz, 1996), and (5) 2x2 goal orientation (learning/performance $\mathrm{x}$ approach/avoidance; Elliot and McGregor; 2001). The most frequently mentioned and utilized model in the literature is the $2 \times 2$ goal orientation model. This model includes the following dimensions; 1) Mastery/ learning-approach: Individuals who have mastery-approach goal orientations aim to develop their knowledge and skills 2) Performance-approach: Individuals who have performanceapproach goal orientation have the tendency to try and show their skills and performance to others (receiving appreciation of others, extrinsic standards) 3) Mastery/learning-avoidance: This orientation includes more negative feelings in relation to learning processes (a fear to realize goals, being worried, having mostly negative feelings) 4) Performance-avoidance: Individuals who have performance-avoidance goal orientation tend to hide their incompetencies from others (not wanting and preventing others from seeing their failures, avoiding help seeking, extrinsic standards) (Dweck, 1990). While the main assumptions regarding goal orientations are defined as above, it is observed that there are opinion differences among theorists in terms of the assumptions surrounding the main dimensions of goal orientations. For example, while Barron and Harackiewicz (2001) accepted mastery/learning goal orientation as an individual's effort to take control of the given task (task standard), Grant and Dweck (2003) describe it as an active effort to develop competencies (intrinsic standard). Those two views resulted in the emergence of new models such as Elliot, Murayama and Pekrun's (2011) 3x2 model (as cited in Daumiller, Dickhäuser, and Dresel, 2019). This model proposed a new goal structure by categorizing goals as selfbased, task-based, and other-based and utilizing a competence based evaluation criteria (task, self, and other).

Teaching in today's world is an important profession where learning does not stop. The school environment is one where teachers display high performance, develop their professional skills throughout their career, and learn new things (Borko, 2004). Therefore, considering that each teacher is at the same time a learner, the way they face difficulties in their job and, the way they respond to and interpret problems they experience can vary (Nitsche et al., 2011). Goal orientations for teachers have an important role in predicting their motivational and teaching performance (Kucsera et al., 2011). There are a number of studies conducted to categorize the different goal orientations that teachers have and various tools have been developed to measure teachers' goal orientations. Those data collection tools are based on the three different goal orientations (learningapproach, performance-approach, performance-avoidance) (Butler, 2007; 2012, Kucsera et al. 2011; Wandevalle, 1997). Butler's $(2007 ; 2012)$ model, on the other hand, included the following; (1) Mastery-approach, (2) Ability-approach, (3) Ability-avoidance, (4) and Work-avoidance. Later on, Butler (2012) added the fifth dimension titled relational to this categorization. Those two dimensions (work-avoidance and relational) are significant because the tasks and responsibilities that teachers (who deal with many people during a day) are given in the workplace can result in differences in individual preferences (Daumiller, Dickhäuser and Dresel, 2019). And it is important to understand whether these preferences have any impact on the learning environment. More details in relation to those orientations as well as the results of research on exploring teachers' behavioural patterns in the classroom are summarized as following: 1) Mastery-approach: Focus on learning, being open to develop professional skills, creating learning focused classroom environments, high self-sufficiency, high interest in the profession, completing the tasks in the best way possible during the process of teaching, providing meaningful learning, and so on. 2) Ability-approach: Wanting others to know their quality teaching skills, being praised, receiving approval, putting competition into the centre of classroom practices, taking skill differences into account, focusing on overachievement, not taking student interests and requests into account, using exam scores as indicators for assessment 3) Ability-avoidance: Not wanting others to know about their low quality teaching skills, avoiding help seeking, avoiding failure, avoiding difficult tasks, preferring easier tasks, looking for external reasons as the source of a problem, and evaluating themselves based on extrinsic standards 4) Work-avoidance: Tendency to display low performance, not wanting to have too much workload, and little interest in school related duties 5) Relational: Establishing close relationships with students and providing social support (Butler, 2007; 2012; Dickhauser, Butler and Toenjes, 2007; Kucsera et al. 2011; Meece, Anderman, and Anderman, 2006; Patrick et al, 2001; Throndsen and Turmo, 2012).

Teachers who have mastery-approach are more focused on professional development, those who have ability-approach or ability-avoidance can have positive or negative behavioural patterns which change depending on extrinsic standards. As for work-avoidance, it refers to teachers avoiding exerting the effort necessary to do their job and trying to do the least amount of work possible. In the relational aspect, on the other hand, the communication established with students and the meaning attached to this communication is examined. The analysis of related literature suggests that goal orientations teachers possessed towards teaching are reflected in their classroom practices. It has been observed that teachers who have masteryapproach conduct classroom activities that are focused on learning and support the active participation of students, 
teachers who have performance-approach, on the other hand, focus on high performance and conduct competition based activities where students are compared with one another.

The analysis of studies on goal orientations indicates mastery/ learning goal orientations are associated with positive behavioural patterns, and performance related goal orientations are either associated with positive behavioural patterns or do not reflect the expected negative behavioural patterns. For example, the results of the study conducted by Janssen and Prins (2007) suggested that employees who had a stronger learningapproach were more focused on developing themselves rather than looking for ways of validation. Additionally, the opposite relationship between performance-approach and performanceavoidance was evident in terms of individuals trying to develop themselves. Similarly, Midgley, Kaplan and Middleton (2001) found that students, in certain situations, can become adaptive learners even though they have performance-approach so long as their mastery/learning goal orientations are high. In addition, King and McInerney's (2014) study with college students suggested that mastery/learning goal orientations were similar across cultures, but other orientations were unique. Those results indicate that further studies (both conceptually and methodologically) are required to be able to better understand the meanings of mastery/learning goal orientations as well as the cultural differentiation of their effects based on contextual factors. Gordon, Dembo and Hocevar (2007), on the other hand, reported that teachers who used mastery control orientation in the classroom had higher levels of humanistic control ideologies, and performance-approach was not found to have any negative relationships with classroom control ideology. Similarly, in her study, Yildizlı (2019) found that ability-approach goal orientation did not have any relationship with self-efficacy or burnout levels.

Another topic of interest is how goal orientations teachers possess affect teaching/learning processes within the classroom. If we classify the learning environments into two (learning and performance goal structure), teachers in performance-oriented learning environments focus on competition within the classroom, group students based on their skills, reward successful students, and prioritize general assessment (Eccles and Roeser, 2011). Teachers in learningoriented classroom environments, on the other hand, prioritize individual learning and development. While learning-oriented classroom environments have positive relationships with all the behaviours expected from today's learners, performanceoriented classroom environments have different outcomes. For example, Elliot and Harackiewicz (1996) found that performance-approach condition was less effective for intrinsic motivation when compared to mastery-approach condition. Karabenick (2004) concluded that performanceapproach goal structure did not have a significant impact on students' help-seeking. And many studies found that goal orientation within the classroom can have different or the same effects on student behaviours (Murayama and Elliot, 2009; Wolters and Daugherty, 2007).

Another debated issue in relation to goal orientations is whether they are generalizable or not. More specifically, do cultural contexts and roles and identities that develop in cultural contexts have a significant role in shaping goal orientations? According to Urdan and Kaplan (2020), the relationship between achievement goal theory and the moral/philosophical views in relation to the aims of schools constitute the proof of the structure of the theory. Various factors (e.g. schools or classrooms serving a wide culture range, the definition of success being affected by certain beliefs, policies, and norms within a given education system, standardized tests conducted in a country, and how schools or classrooms define success) affect the structure of goal orientations. Considering the complexity of teaching/learning processes and the complexity of human beings, the need arises to answer the following question: Does this situation allow individuals to combine different types of goal orientations in an effort to continue their achievement in different circumstances? Therefore, the need arises to investigate in more detail the meanings and structures of mastery/learning goal orientations considering contextual factors. As such, it is noted in the literature that the methodologies utilized to investigate goal orientations with different populations should go beyond experiments and questionnaires, and expand towards more qualitative methodologies utilizing open-ended and inductive approaches (Urdan and Kaplan, 2020). As mentioned above, school and classroom are environments that form various behavioural patterns as a result of the interactions between different dynamics. Questions that will provide details about how individuals organize their lives and what meanings they attach to those experiences should be asked to collect in-depth data. As such, an in-depth picture can be depicted about teachers' viewpoints via the answers that reflect their viewpoints.

In line with this aim and significance, and taking goal orientations teachers have towards teaching into consideration, answers to the following research questions were sought:

1. What are the emotions, views, and actions of teachers with Learning-Mastery-Goal Orientations (L-M-GO) and Learning-Mastery-Performance-Goal Orientations (L-M-P-GO) towards teaching?

2. What kinds of classroom practices are reported by teachers with L-M-GO and L-M-P-GO orientations?

\section{METHOD}

The goal of the study was to reveal the emotions, views, and actions of in-service teachers in the context of goal orientations towards teaching including; mastery/learning, abilityapproach, ability-avoidance, work-avoidance, and relational goal orientations. Teachers' classroom practices were also examined based on goal orientations they had. A qualitative research methodology was adopted to reach the objectives of the study. The data were collected via a questionnaire and semi-structured interviews.

\section{Study group}

10 in-service teachers working in Turkey were the participants. Those teachers were at the same time the students of the author as part of the Master's degree they were completing. A number of meetings were organized in order to explain the theoretical information on goal orientations and discuss it with the teachers. The reason for conducting those meetings was 
to allow the participants to utilize the theoretical knowledge they received in describing and evaluating themselves in the context of goal orientations... Demographic information on the participants is provided in Table 1 .

\begin{tabular}{llll}
\multicolumn{1}{c}{ Gender } & $\boldsymbol{f}$ & \multicolumn{1}{c}{ Subject } & $f$ \\
\hline Male & 2 & Foreign languages & $4^{*}$ \\
\hline Female & 8 & Mathematics & 1 \\
\hline \multicolumn{1}{c}{ School } & & Classroom teacher & 4 \\
\hline Kindergarten & 3 & Turkish & 1 \\
\hline Elementary school & 4 & Kindergarten teacher & 1 \\
\hline Secondary school & 4 & Teaching experience & \\
\hline High school & 3 & 0-5 years & 3 \\
\hline & & 5+ years & 7 \\
\hline
\end{tabular}

*: indicates that teachers served in more than one type of school

Table 1: Demographic characteristics of the participants

\section{Data collection procedures}

The data were collected utilizing a semi-structured interview schedule and a questionnaire. The following steps were followed:

1. Teachers (those who actively taught in a school) among the researcher's Master's degree students were identified and they were asked if they would volunteer in the study. Ethical approval was received to conduct the study. The fact that participating teachers were MA students was significant since the study required participants to possess a certain level of cognitive and affective awareness to explore and evaluate a theoretical construct.

2. Those 10 teachers were initially invited to meetings (a total of four meetings) which were held to provide teachers with theoretical information on goal orientations.
3. Teachers were then asked to describe and evaluate themselves in terms of goal orientations. The descriptions that teachers made were then categorized as learning and performance related approaches and presented in Table 2 .

4. Face-to-face interviews were held with teachers who evaluated themselves in the context of goal orientations towards teaching. Initial coding was carried out following each interview and additional questions were added to the interview schedule for the following interviews to allow comparisons. This allowed the researcher to conduct reflective investigations.

5. Afterwards, teachers were asked to complete the questionnaire to allow the researcher to collect in-depth information regarding teachers' classroom practices.

\begin{tabular}{lc}
\multicolumn{1}{c|}{ Goal orientation } & Teacher code \\
\hline Learning/mastery goal orientation (L-M-GO) & $\mathrm{T} 1, \mathrm{~T} 2, \mathrm{~T} 4, \mathrm{~T} 5, \mathrm{~T} 6$ \\
\hline Learning/mastery-performance goal orientation (L-M-P-GO) & $\mathrm{T} 3, \mathrm{~T} 7, \mathrm{~T} 8, \mathrm{~T} 9, \mathrm{~T} 10$ \\
\hline
\end{tabular}

Table 2: Teachers goal orientation descriptions

\section{Data collection tools}

Two data collection tools were utilized in this study; goal orientations view form and classroom practices view form. Both tools were developed by the researcher.

1. Goal orientations interview schedule "Goal Orientations for Teaching Scale" developed by Butler $(2007,2012)$ was adapted into Turkish by Y1ldizlı et al. (2016). The scale included; mastery, ability-approach, abilityavoidance, work-avoidance, and relational categories. Interview questions were prepared considering those factors. Following the preparation of the questions, subject matter experts were consulted to check whether the questions reflected the topic of research and whether they were in line with the theoretical framework and understandable in terms of the language used. Questions were revised and finalized based on experts' comments. During the interviews, probes and prompts were used where necessary in order to gather more detailed answers. Sample interview questions included:
(1) As a teacher, how would you evaluate your learning processes? Can you provide examples? What actions do you take? (2) What meaning do you attach to the principal and other colleagues seeing and hearing your success stories? Would you be happy? Would this situation further motivate you in your job? Or does it not matter that others view you as a successful teacher? Can you say that it is not important that they do not realize this situation? What do you think about this?

2. The other data collection tool utilized in the study was the classroom practices questionnaire. This form was utilized to reveal what teachers did in the classroom and what meaning(s) they attached to their practices. Similar to the first tool, experts were also consulted to revise this tool. Sample questions in the questionnaire included: (1) Are students' levels different in your classroom? If so, what activities do you carry out for lower-level students? (2) What do you think about the exams that you prepare? 
There is not much difference between students' level in my classroom. Nevertheless, differences are observed. Therefore, I try to create an individual learning environment and provide one-to-one support in lectures. Moreover, I do not time exercises for the whole group, instead, I time them individually. While students who complete a given exercise can continue to the next exercise, students who have lower levels do not have difficulties in reaching others; they follow the pace they are comfortable with.

ndividual learning Lecture based One-to-one support Individual activity completion times

Table 3: Sample coding chart used in the study

\begin{tabular}{|c|c|}
\hline \multicolumn{2}{|c|}{ 1. Codes in relation to goal orientations } \\
\hline Third round of coding & Second round of coding \\
\hline 1.a. Student-teacher's learning journey & $\begin{array}{l}\text { 1.a.1. Reasons } \\
\text { 1.a.2. Thinking like a student } \\
\text { 1.a.3. Lack of knowledge } \\
\text { 1.a.4. Seeking solutions } \\
\text { 1.a.5. The final outcome }\end{array}$ \\
\hline $\begin{array}{l}\text { 1.b. Situations where teachers show the } \\
\text { tendency to avoid work }\end{array}$ & $\begin{array}{l}\text { 1.b.1. Reasons } \\
\text { 1.b.2. Behavioural patterns } \\
\text { 1.b.3. Outcome }\end{array}$ \\
\hline 1.c. Teachers' relationships with students & $\begin{array}{l}\text { 1.c.1. Good relationship } \\
\text { 1.c.1.1. Indicators of the relationship } \\
\text { 1.c.1.2. Outcome of the relationship } \\
\text { 1.c.2. Respectful relationship } \\
\text { 1.c.2.1. Indicators of the relationship } \\
\text { 1.c.2.2. Outcome of the relationship }\end{array}$ \\
\hline 1.d. Others learning about successes-failures & $\begin{array}{l}\text { 1.d.1. Success-failure } \\
\text { 1.d.2. Others learning about successes-failures } \\
\text { 1.d.3. Outcome }\end{array}$ \\
\hline \multicolumn{2}{|c|}{ 2. Codes in relation to classroom practices } \\
\hline $\begin{array}{l}\text { 2.a. Taking individual differences into account } \\
\text { and classroom learning activities }\end{array}$ & $\begin{array}{l}\text { 2.a.1. Classrooms } \\
\text { 2.a.2. Processes } \\
\text { 2.a.3. Outcome }\end{array}$ \\
\hline 2.b. Exams & $\begin{array}{l}\text { 2.b.1. The meaning and importance of exams } \\
\text { 2.b.2. Issues focused on in exam papers } \\
\text { 2.b.3. Sharing exam scores in the classroom }\end{array}$ \\
\hline 2.c. Within class comparisons & $\begin{array}{l}\text { 2.c.1. Importance of scoring high } \\
\text { 2.c.2. Emphasis on being the best in academic } \\
\text { achievement } \\
\text { 2.c.3. Classroom comparison- showing model } \\
\text { students }\end{array}$ \\
\hline 2.d. Making mistakes and supporting efforts & $\begin{array}{l}\text { 2.d.1. Making mistakes } \\
\text { 2.d.2. Supporting efforts }\end{array}$ \\
\hline
\end{tabular}

Table 4: The second and third round categories developed in the study

\section{Data analysis}

1. The data collected from semi-structured interviews and the questionnaire were transformed into digital files.

2. The sentences that each participant uttered were analysed and coded separately. This was the first round of coding.

3. Following the first round of coding, basic analytic techniques such as summarizing and comparisons were utilized. The rationale was to explore whether there were practice and/or view differences between teachers who had different goal orientations. In order to achieve this, each participant's statements were summarized as a paragraph and the codes attached to their statements were organized into columns. The reason for creating tables was to allow the researcher to scan for patterns in the data, develop theses, and explore different aspects in relation to a given code (Miles, Huberman and Saldaña, 2014). A sample coding relating to the first round of coding is provided in Table 3.

4. The second round of coding utilized the codes which emerged in the first round and those codes were categorized

5. In the third and final round of coding, the categories that were developed were re-coded in line with the questions used. Table 4 includes a detailed map summarizing the data. Please note that the codes that emerged in the first round of coding are detailed in the results. The second and third round codes are not given in Table 4 in order to prevent repetition. 
6. The data were organized taking the reported goal orientations of the participants into account (i.e. L-M-GO or L-M-P-GO) to facilitate the process of making comparisons (i.e. finding similarities and/or differences).

7. The processes during which the data were coded are detailed in the present research. At the end of one-on-one interviews, member checks were done in order to confirm the researcher's interpretation of the data. Participants were individuals with whom the author had contact with for a long time and, in return, this helped to establish a friendly environment encouraging honest responses. Last but not least, direct quotations were used to support the interpretations of the researcher.

\section{RESULTS}

1. Teachers' emotions, views, and actions in relation to goal orientations they possessed

\section{1.a. Student-teacher's learning journey}

All of the teachers participating in the study, as mentioned before, described themselves as learning-focused teachers. In their descriptions, teachers used terms such as "studentteacher", "never-ending student life", and "being a student forever". The researcher deemed "student-teacher's learning journey" appropriate as the higher hierarchical code in relation to those descriptions. The emotions and views teachers had and the actions they took in relation to this topic were coded within this sub-section and presented in Table 5 .

\begin{tabular}{|c|c|c|c|c|c|}
\hline & Reasons & Thinking like a student & Lack of knowledge & Seeking solutions & The final outcome \\
\hline 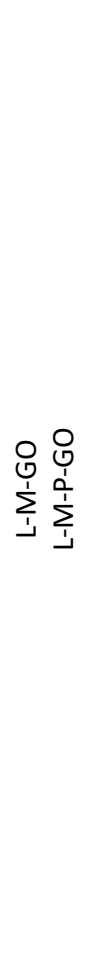 & 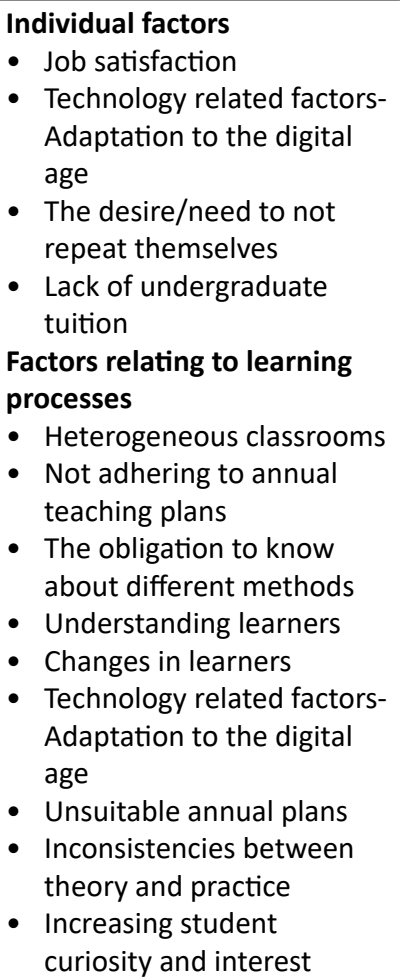 & $\begin{array}{l}\text { - Trying to learn like } \\
\text { students } \\
\text { - Questioning what } \\
\text { can be done } \\
\text { - Not being bothered } \\
\text { by learning }\end{array}$ & $\begin{array}{l}\text { Positive emotions and } \\
\text { views } \\
\text { - Not knowing is an } \\
\text { advantage } \\
\text { - Not knowing } \\
\text { is a natural } \\
\text { phenomenon } \\
\text { - The teacher cannot } \\
\text { know everything } \\
\text { - Important for } \\
\text { doing research and } \\
\text { development } \\
\text { Negative emotions and } \\
\text { feelings } \\
\text { - Embarrassment from } \\
\text { not researching } \\
\text { - Sadness from not } \\
\text { knowing* } \\
\text { - Uneasiness } \\
\text { - Concerns of having } \\
\text { too many things to } \\
\text { learn* }\end{array}$ & $\begin{array}{l}\text { - Seeking different } \\
\text { teaching } \\
\text { approaches } \\
\text { - } \text { Following } \\
\text { platforms } \\
\text { - } \text { Reading from } \\
\text { various sources } \\
\text { - Following } \\
\text { webinars } \\
\text { - Meeting } \\
\text { colleagues from } \\
\text { different countries } \\
\text { - Receiving post- } \\
\text { graduate tuition } \\
\text { - Receiving help } \\
\text { from colleagues } \\
\text { - Participation in } \\
\text { workshops }\end{array}$ & $\begin{array}{l}\text { - } \text { Sharing new } \\
\text { experiences with } \\
\text { students } \\
\text { - Showing that teachers } \\
\text { are also learner } \\
\text { - } \text { Learning with } \\
\text { students } \\
\text { - Loving to learn } \\
\text { - Loving the sharing of } \\
\text { ideas } \\
\text { - Learning new things } \\
\text { is fun } \\
\text { - Enjoyment and } \\
\text { happiness from } \\
\text { learning } \\
\text { - Staying updated } \\
\text { - Learning how to do } \\
\text { - } \text { valid research } \\
\text { - Increative plans } \\
\text { - } \text { accumulation. } \\
\text { Creating a research } \\
\text { interest among } \\
\text { students } \\
\text { teacher is motivated }\end{array}$ \\
\hline
\end{tabular}

*: Codes that emerged from the data that teachers who had L-M-P-GO

Table 5: Student-teacher's learning journey

As can be seen in Table 5, teachers' learning journey was depicted using second-cycle codes such as reasons, thinking like a student, lack of knowledge, seeking solutions, and the final outcome. The reasons that pushed teachers to learn were categorized as individual factors and factors relating to learning processes. Individual reasons and factors relating to learning processes pushed teachers to learn. For example, T1 stated that "student profile [was] continuously changing... technological factors [were] in the foreground". On the other hand, T3 noted that their "teaching styles changed based on the students. The dynamics of different classrooms could be very different. There could be students who experience learning difficulties [and] some classrooms can be very homogeneous". It has been observed that teachers questioned themselves like students and they were not uncomfortable with being in process of meta- cognitive learning where they thought about what they could do. For example, T7 expressed that they "were aware that [they] had a profession whose responsibility was really high and [they] tried to follow the most recent developments in [their] field". T2 noted that they "tried to think like a student when [they] got prepared for teaching".

The analysis of positive and negative emotions and views teachers had during this process indicated that not knowing is a normal situation for teachers and it is what is necessary for doing research and development. In relation to this T1 remarked that they "considered being able to make up for the areas where they lacked in as an advantage". Likewise, T6 noted "not knowing something felt like a natural process since everything changed so fast". And T4 stated their "selfconfidence increased as they learned more". It has also been 
observed that teachers who experienced negative emotions and had negative views were mainly teachers who had L-M-P-GO. Those teachers associated not knowing with emotions and views such as "sadness, embarrassment, concerns of too many things to learn, and sadness for not having learned something before". For example, T3 stated that they "wished they had learned it before. [They] experienced anxiety and started to think about how [they] would learn all of those". Similarly, T7 expressed that they "felt very sad when they realized that they did not know something". The way teachers sought solutions for problems experienced in learning processes were similar. The final outcomes that teachers experienced in relation to learning processes, on the other hand, included both positive and negative expressions. For example: sharing their newly acquired experiences with students; showing that the teacher is also a student; learning with students; the enjoyment happiness and pleasure that learning new things gives; being able to stay updated; increasing knowledge; making creative plans; and so on. For example, T9 reported that "there were so many things that they learned thanks to them [students]". T6 stated that "learning new things was an enjoyable process. [They] liked trying out the new things [they] learned about and observing the outcomes".

\section{1.b. Situations where teachers show the tendency to avoid work}

The analysis of Table 6 suggests that there were situations where all teachers avoided work in school/classroom. Second cycle codes included reasons for avoiding work, teacher behaviours in the work environment, and the outcomes. The reasons why teachers avoided work were coded as: redundant tasks to show off; the principal's wish to be popular, the wish to make a name for the school, activities where managers consider their own benefit, activities where the number of participants is important, compulsory group work, compulsory projects, and unawarded works. For example, T2 underlined that "what decreases [their] energy is being asked to complete redundant tasks and formalities. [They] did not like the word 'project' at all... It disturbed them that principals kept teachers busy so that they could benefit from teachers' efforts. [They] did not want to do the tasks that managers designed considering their own benefit". As a result of assigning tasks to teachers on a compulsory basis, teachers become unwilling to participate in projects, avoid expressing their opinions, try to complete a given task as soon as possible, are not able to completely devote themselves to the given task, or do not display behaviours that are aimed to develop group work. The following conclusion is drawn based on teachers' statements: conducting activities in a way that those activities lose their essence, teachers considering what they are asked to do to not correlate with teaching, and forcing and boring students result into ineffective group work. In relation to this, T1 noted that "there were too many activities in MEB [referring to public schools]. Those activities tired [them] out... Conducting those activities in a way that they lose their essence prevented those activities from serving their purpose. The events were organized as a formality. Students did not participate voluntarily. [They] preferred avoiding compulsory events, both [their] students and [they].

\begin{tabular}{|c|c|c|c|}
\hline & Reasons & Behavioural patterns & Outcome \\
\hline $\begin{array}{l}0 \\
\text { O } \\
\\
1 \\
\sum_{1}^{1} \\
1 \\
1 \\
1\end{array}$ & $\begin{array}{l}\text { - Redundant tasks to show off } \\
\text { - Activities where managers consider their } \\
\text { own benefit (concern of losing their } \\
\text { positions, the wish to be popular) } \\
\text { - Activities where the number of } \\
\text { participants is important } \\
\text { - The wish to make a name for the school } \\
\text { - Compulsory group work } \\
\text { - Compulsory projects } \\
\text { - Unawarded work }\end{array}$ & $\begin{array}{l}\text { - Unwillingness to participate } \\
\text { in projects } \\
\text { - Avoiding expressing an } \\
\text { opinion } \\
\text { - Completing the task as soon } \\
\text { as possible } \\
\text { - Not being able to completely } \\
\text { devote the self to the task } \\
\text { - Not displaying behaviours } \\
\text { that develop group work }\end{array}$ & $\begin{array}{l}\text { - Completing activities in } \\
\text { a way that the activities lose } \\
\text { their essence } \\
\text { - Considering what they are } \\
\text { asked to do to not correlate } \\
\text { - } \text { with teaching } \\
\text { - } \text { - Puck of fair assessment } \\
\text { - Boring students } \\
\text { - Ineffective group work }\end{array}$ \\
\hline
\end{tabular}

Table 6: Situations where teachers show the tendency to avoid work

\section{1.c. Teachers' relationships with students}

Table 7 provides information on teachers' views with regards to their relationships with students. Teachers' responses indicated two types of relationship; a good relationship and a respectful one. Indicators of teachers having a good relationship were as following: students not being afraid of the teacher, students becoming happy when they see the teacher, teachers supporting students and, spreading positive energy, voluntary participation in social events, valuing the relationship with students, being able to comfortably express emotions, establishing eye contact, focusing on love, and spending time with students outside the school. In relation to this, T4 stated that they "preferred that students considered [them] as friends. This way, they [the students] could more easily share their feelings and ideas with them [the teacher]".
Similarly, T6 noted they "had relationships with students which were based on love. It was thanks to the relationships [they] established with students that [they] were able to meet with students outside the school frequently". A number of positive outcomes of the good relationship with students were reported by the teachers. For example, creating a positive atmosphere in the school, creating a perception that the school is an opportunity, both teachers and students becoming more self-aware, mapping the school as a good entity in students' minds, development of empathy, preparing plans that prioritize feelings and emotions, professional development, preparation for life, students becoming responsible, and decreasing expectations of reward. It is worth noting that few teachers (male and working in high schools) who had L-MGO underlined that there should be a respectful relationship 
between teachers and students. T2 expressed the situation with following words: "II preferhaving a certain distance with the students... Students do not know where to stop". Keeping a distance with the students, concerns of students not knowing their positions, students paying more attention to their behaviours when they encounter the teacher, and students' careful selection of words to use when they talk to the teacher were among the reasons that male high school teachers wanted to have a relationship with students that was found on respect. Those teachers added that such a relationship teaches students how to behave respectfully in society.

\begin{tabular}{|c|c|c|}
\hline & \multicolumn{2}{|c|}{ Good relationship } \\
\hline & Indicators of the relationship & Outcome of the relationship \\
\hline \multirow[t]{2}{*}{$\begin{array}{l}0 \\
\text { O } \\
\substack{1 \\
1} \\
\sum_{i}^{1} \sum_{i}^{1}\end{array}$} & $\begin{array}{l}\text { - Students not being afraid of the teacher } \\
\text { - } \text { Students becoming happy when they see the } \\
\text { - Supporting students } \\
\text { - Spreading positive energy } \\
\text { - Voluntary participation in social activities } \\
\text { - Valuing the relationship with students } \\
\text { - Trying to directly express themselves } \\
\text { - Expressing emotions comfortably } \\
\text { - Establishing eye contact } \\
\text { - Focusing on love } \\
\text { - Being able to spend time with students outside } \\
\text { the school }\end{array}$ & $\begin{array}{l}\text { - Creating a positive atmosphere in the school } \\
\text { - Creating the perception that school is an } \\
\text { - } \text { opportunity } \\
\text { - Mecoming self-aware } \\
\text { - } \text { minds } \\
\text { - Tnowing the students } \\
\text { - Preparing the teacher } \\
\text { - Professional development } \\
\text { - Students' development of empathy } \\
\text { - Preparing plans that give importance to feelings } \\
\text { - Responsible students } \\
\text { - Students who can find solutions to problems } \\
\text { - Decreasing expectations of reward }\end{array}$ \\
\hline & \multicolumn{2}{|c|}{ Respectful relationship } \\
\hline$\sum_{\substack{1\\
}}^{1}$ & $\begin{array}{l}\text { - Keeping a distance with the students } \\
\text { - Concerns of students not knowing their positions } \\
\text { - Students paying more attention to their } \\
\text { behaviours when they encounter the teacher } \\
\text { - Careful selection of words }\end{array}$ & $\begin{array}{l}\text { - Learning how to behave respectfully in the } \\
\text { society } \\
\text { - Learning how to respect }\end{array}$ \\
\hline
\end{tabular}

*: Teachers who focused on respectful relationship were male teachers who worked in high schools

Table 7: Teachers' relationships with students

\section{1.d. Others learning about successes-failures}

The analysis of codes in Table 8 indicates that teachers described being successful as spreading positive energy, getting students to like the lesson, increasing the trust students have in the teacher, observing that students in the classroom are happy, increases in students' academic achievements, diversifying professional experiences, development of students' ideas, development of humanitarian values among student, receiving positive feedback, establishing parentschool coordination, showing parent responsibility, and sharing professional knowledge with others. In relation to this, T1 expressed: "Teachers who know their students, help them, and want to spend time with them are successful teachers. Those who enable students to get to know themselves, transform the school atmosphere into a positive one, and spread positive energy are successful". Regardless of teachers' goal orientations, all teachers wanted others to know about their successes. Teachers considered that when others know about their successes then those successes become a source of motivation, enable them to be tagged as role-model teachers, develop perceptions of an organized school, increase their sufficiency beliefs, and develop perceptions of a trust source. All those processes create the feelings of enjoyment, happiness, and pride among teachers.
In relation to this, T4 expressed they "would feel happy if they were able to serve as role models to others. That others acknowledged and appreciated [them] pleased [them]". Likewise, T8 noted that they "wanted others to know and respect that [they] did their job good". It is understood that teachers want to experience success and want others to know about their successes. The analysis of the failure dimension, on the other hand, suggested that teachers described failure as students' academic underachievement, students being afraid of the teacher, teachers not developing themselves professionally, teachers not loving their jobs, and teachers not receiving positive feedback from their environment. While all teachers wanted others to learn about their successes, none of them wanted their failures to be learned about. Furthermore, teachers perceived that failures demotivate them from doing their job, increase beliefs of inefficacy, and create the image of a bad teacher. Failures result in experiences of sadness, regret and embarrassment. In relation to this, $\mathrm{T} 2$ remarked that they "would become disturbed if others learned about a negative incident that took place between the teacher and students". Similarly, T4 underlined that "unfortunately, [their] love and enjoyment for [their] job would be negatively affected”. 


\begin{tabular}{|c|c|c|c|}
\hline \multirow{4}{*}{$\begin{array}{l}0 \\
\text { O } \\
\bigcup_{1}^{1} \\
\sum_{i}^{1} \sum_{i}^{1}\end{array}$} & Success & Others learning about successes & Outcome \\
\hline & $\begin{array}{l}\text { - Spreading positive energy } \\
\text { - Getting students to like the lesson } \\
\text { - Trust in the teacher } \\
\text { - Happy students in the classroom } \\
\text { - Increase in academic success } \\
\text { - Diversifying professional experiences } \\
\text { - Developing students' ideas } \\
\text { - Development of humanitarian values } \\
\text { - Receiving positive feedback } \\
\text { - Establishing parent-school coordination } \\
\text { - Showing parent responsibility } \\
\text { - Sharing professional knowledge with } \\
\text { colleagues }\end{array}$ & $\begin{array}{l}\text { - } \\
\text { - Role-model teacher } \\
\text { - Source of motivation } \\
\text { - Rerception of an organized school } \\
\text { - Increasing appreciation } \\
\text { - Increasing beliefs of self-efficacy } \\
\text { - Source of trust }\end{array}$ & $\begin{array}{l}\text { - Happiness } \\
\text { - Enjoyment } \\
\text { - Pride }\end{array}$ \\
\hline & Failure & Others learning about failures & Outcome \\
\hline & $\begin{array}{l}\text { - Students' academic underachievement } \\
\text { - Students being afraid of the teacher } \\
\text { - Teachers not developing themselves } \\
\text { professionally } \\
\text { - Teachers not loving their jobs } \\
\text { - Teachers not receiving positive feedback } \\
\text { from their environments }\end{array}$ & $\begin{array}{l}\text { - Job demotivation } \\
\text { - Beliefs of insufficiency } \\
\text { - Bad teacher } \\
\text { - Not wanting others to learn }\end{array}$ & $\begin{array}{l}\text { - Sadness } \\
\text { - Regret } \\
\text { - Embarrassment }\end{array}$ \\
\hline
\end{tabular}

Table 8: Others learning about successes-failures

\section{Findings on teachers' classroom practices}

Differences between teachers' classroom practices in terms of their goal orientations are presented in this section. Classroom practices were analysed under the following sub-headings; (1) taking individual differences into account and classroom learning activities, (2) exams, (3) in-class comparisons, (4) making mistakes and efforts and (5) in-class competition.

\section{2.a. Taking individual differences into account and classroom activities}

Table 9 indicated that crowded classrooms were an important factor for teachers in paying attention to individual differences. Regardless of their goal orientations, teachers reported that they grouped students in crowded classrooms based on their levels, in other words, teachers did their teaching based on the level of an average student. Furthermore, some of the teachers with L-M-GO orientations reported that they grouped students as low, medium, and high level groups and did their teaching considering the average level in each group. For example, T1 explained: "The level of students that I teach are different from one another. On average, a classroom has 45 students. Whilst teaching, I assume that the students have one of the three levels of success; low, medium, or high. And I plan my lesson accordingly". Similarly, T9 noted that "if there are students who have high and low levels of intelligence then [they] would teach the class according to medium level student". Teachers with L-M-GO orientations explained that if learning did not occur then they found the solution by providing students with extra-curricular activities (i.e. supporting courses). For example, T1 stated "I try to find extra-curricular activities for students whose level is low.
For this purpose, I opened a course on brain teasers and tried to include those low-level students". Teachers with L-M-P-GO orientations, on the other hand, explained that they tried to use various strategies such as re-explaining the topic, giving extra homework, and creating heterogeneous groups of students with different levels to allow peer learning. For example, while T9's solution was to “ask students who managed to complete the given task to help another student who has not completed the task", T10 explained that they "gave extra homework and checked whether it was done". In classrooms that were not crowded, teachers with both goal orientations tried to follow one-to-one instruction. Teachers stated that they gave extra homework, checked students outside the school, and so on.

Additionally, regardless of their goal orientations, teachers reported to have used various methods, techniques, and strategies that supported learning in the classroom. In relation to this, T1 underlined that " $[i] n$ addition to the texts and activities in the coursebook, [they] included activities such as drama, theatre, and brain teasers which the pupils enjoyed having" and T10 explained they tried to facilitate learning by "getting students to play group games, digital word games, and word games in the school yard which aimed to develop students 'pronunciation". 


\begin{tabular}{|c|c|c|c|}
\hline \multicolumn{4}{|c|}{ Taking individual differences into account } \\
\hline Orientation & Classroom & Process & Outcome \\
\hline \multirow{3}{*}{$\begin{array}{l}\text { O } \\
\sum_{i}^{1} \\
\end{array}$} & \multirow{3}{*}{ Crowded classrooms } & $\begin{array}{l}\text { Grouping students as high, medium, and low } \\
\text { level }\end{array}$ & Teaching the lesson based on this grouping \\
\hline & & Identifying the average student level & $\begin{array}{l}\text { Teaching the lesson according to the level of } \\
\text { the average student }\end{array}$ \\
\hline & & If learning has not taken place in the classroom & $\begin{array}{l}\text { Out of class activities (i.e. extra courses) and } \\
\text { guidance }\end{array}$ \\
\hline \multirow{4}{*}{$\begin{array}{l}\text { O } \\
\text { I } \\
1 \\
0_{1}^{1} \\
\sum_{1}^{1}\end{array}$} & \multirow{4}{*}{ Crowded classrooms } & \multirow{4}{*}{ Identifying the average student } & $\begin{array}{l}\text { Putting students who have different levels in } \\
\text { the same group and allowing peer learning }\end{array}$ \\
\hline & & & Giving extra homework \\
\hline & & & Re-explaining up to three times \\
\hline & & & $\begin{array}{l}\text { Peer-support (enabling students to learn } \\
\text { from their peers) }\end{array}$ \\
\hline \multirow{8}{*}{$\begin{array}{l}0 \\
0 \\
0 \\
1 \\
\sum_{1}^{1} \sum_{1}^{1} \\
\sum_{1}^{1}\end{array}$} & \multirow{8}{*}{ Less crowded classrooms } & Supporting individual learning & $\begin{array}{l}\text { Allowing lower level students to experience } \\
\text { a sense of accomplishment }\end{array}$ \\
\hline & & One-to-one support & Enabling the realization of individual learning \\
\hline & & \multicolumn{2}{|l|}{$\begin{array}{l}\text { Activity completion times based on students' } \\
\text { levels }\end{array}$} \\
\hline & & \multicolumn{2}{|l|}{$\begin{array}{l}\text { Worksheets designed for different level } \\
\text { students }\end{array}$} \\
\hline & & \multicolumn{2}{|l|}{ Utilizing educational technologies } \\
\hline & & \multicolumn{2}{|l|}{ Receiving support from the family } \\
\hline & & \multicolumn{2}{|l|}{ Extra homework } \\
\hline & & \multicolumn{2}{|l|}{ Out of class checks } \\
\hline \multicolumn{4}{|c|}{ Classroom learning activities } \\
\hline & \multicolumn{3}{|c|}{ Giving students the right to select (taking students views into account) } \\
\hline & \multicolumn{3}{|c|}{ Activities that relate to daily life (using the school environment, exemplifications, using analogies) } \\
\hline & \multicolumn{3}{|c|}{ Effective teaching-learning strategies } \\
\hline & \multicolumn{3}{|c|}{ Creating a democratic environment } \\
\hline & \multicolumn{3}{|c|}{ Freedom in completing activities } \\
\hline & \multicolumn{3}{|l|}{ Out of class project tasks } \\
\hline & \multicolumn{3}{|c|}{ Educational games, competitions, drama } \\
\hline & \multicolumn{3}{|l|}{ Cooperation-based activities } \\
\hline & \multicolumn{3}{|c|}{ Development of higher order thinking skills (problem-solving, critical thinking, creativity, and so on) } \\
\hline & \multicolumn{3}{|l|}{ Parent participation } \\
\hline & \multicolumn{3}{|c|}{ Drama practices and utilizing the resulting materials for teaching (i.e. poems, songs, and so on) } \\
\hline
\end{tabular}

Table 9: Codes on taking individual differences into account and classroom activities

\section{2.b. Exams}

The analysis of Table 10 suggests that there were significant differences between teachers' exam practices based on their goal orientations. All teachers, regardless of their goal orientations, perceived the exams to be important tools for teachers and students alike to evaluate their development. For example, T1 stated: "I consider exams and all types of assessment to be important. This is because such kinds of assessments help not only me [the teacher] but also the students to see their own development and make arrangements accordingly". Similarly, teachers with both goal orientations perceived that exams were not sufficient to find out students' development levels and agreed that the whole learning process should be evaluated. To provide an example, T5 noted "[They] tried to explain [to students] that [the exams] are tools of evaluation so that [the teacher] can see the areas where students need further support with and this was a situation that [the teacher] can compensate for". Similarly, T7 underlined "[They] definitely thought that [they] should evaluate students. Of course, exam scores remain in the background, exams are for observing [students'] development". T2 stated "Evaluation is one of the most important parts of teaching-learning processes; however, [they] did not consider exams to be sufficient to make a judgement about the students". The analysis of responses given by teachers suggested that teachers considered evaluating the whole semester, using formative assessment, evaluating the efforts students made in the classroom, and considering individual development reports. While there was no difference between teachers with different goal orientations in terms of the importance and meaning given to exams, differences were observed with regards to teachers' perceptions of whether exam results should be announced in front of all members of a classroom. Teachers with L-M-GO orientation perceived that student scores should not be shared in front of all students in the classroom for various reasons such as the possibility of damaging students' positive emotions, not being ethical, 
the possibility of causing negative emotions such as jealousy and hostility, and the importance of evaluating each student individually. In relation to this point, T4 expressed they "did not share exam scores publicly in the classroom... This was extremely important to [the teacher]. It was important to prevent the creation of a competitive learning environment based on exam scores so that students who scored low would not be offended". On the other hand, teachers with L-M-P-GO orientations shared the view that exam scores should be announced publicly in the classroom. Their reasoning was based on their perception that it was important to announce the most successful students in a classroom so that they could be appreciated by others in the classroom, and show that success can be achieved by studying hard. Teachers with this goal orientation also expressed that they were fair in scoring exam papers and they wanted to show students that they were fair by sharing the exam scores with the whole class. For example, T10 explained they "wanted to show them [the students] that one can become successful when they study hard and announced the exam scores publicly in the classroom to show it". T9, on the other hand, noted that they "wanted to make sure they were fair in scoring students' papers since exam scores were important for students. Therefore, they shared scored exam papers with students and wanted students to check whether [the teacher] correctly scored [students'] papers. Moreover, [the teacher] also wanted students to see the mistakes they did (i.e. lack of knowledge, operation mistake, and so on)". Additionally, situations that teachers focused on in exam papers were investigated. The results indicated that teachers -regardless of goal orientations- ensured that students were able to realize the mistakes they did in the exam, checked the answers they provided in the exam, identified the areas which they needed further support with, and questioned themselves in an effort to understand why they were not able to correctly answer a problem or question. Few teachers with L-M-PGO orientations explained that they distributed exam papers to students to confirm that they correctly marked and scored students' papers. T9's above statement is an example of this case. In addition, T3 expressed they "wanted [students] to realize their mistakes and try to figure out why they might have done it wrong".

A tool for teachers to observe self-development

L-M-GO Exams are important tools that A tool to observe student development

L-M-P-GO show students' development. Failing those who make mistakes Assessing learning outcomes

Assessing the whole semester

Formative assessment

Assessing efforts in the classroom

Supporting exam point of view

Understanding the areas students need support with and providing that support

L-M-GO Exams are not the only important

L-M-P-GO tool to evaluate student learning.

Taking individual development reports into account

Exams not being able to sufficiently contribute to the process of identifying students' levels

Taking students' performance into account

Using homework as a supportive learning tool

Focusing on the development is important

\begin{tabular}{cll} 
& & \multicolumn{1}{c}{ Situations focused on in exam papers } \\
\cline { 2 - 2 } L-M-GO & Focusing on mistakes/errors & Asking students to check their answers \\
\cline { 2 - 2 } & Identifying the areas students need further support with \\
\cline { 2 - 2 } & Asking students why they could not do a certain part of the exam \\
\hline L-M-P-GO & Confirming that the teacher marked the paper correctly \\
& & Sharing exam scores in the class
\end{tabular}

The most successful students should be presented.

Being appreciated by other students is important.

It is important to show the classroom that the teacher is fair.

L-M-P-GO Exam scores should be shared in It is important to show that everybody receives the score they deserved. the classroom because...

It is a means to show that the teacher is right.

It increases motivation.

It is a means to show others that "when you study you succeed".

It is not ethical to share student scores.

Exam scores should not be

L-M-GO shared in the classroom because...
It can cause negative emotions such as jealousy, hostility, and so on.

Children who had good emotions can suffer.

It is important to evaluate each student individually.

Exam scores should be explained to students one by one to provide individual support.

Table 10: Teachers exam practices 


\section{2.c. In-class comparisons}

As can be seen in Table 11, teachers' responses in relation to in-class comparisons were organized under three categories; the importance of scoring high in the exams, emphasis on being the best in academic success, and in-class comparisons and highlighting model students. The data indicated that all teachers considered scoring high in exams meant happiness for teachers and students, and was a source of motivation and a tool for teachers to evaluate themselves. In relation to this, T2 shared they considered "high scores suggest that the learning activities had been successful. It was also important to [the teacher] since it would increase student motivation which would be worth the efforts". Teachers with L-M-P-GO orientations, on the other hand, considered scoring high in exams as an indicator of being a good teacher and proof of student learning. They also perceived it would be a positive source of motivation for other students in the classroom. In fact, few teachers perceived that working harder pays off with high scores and serves as proof for less successful students. What should be emphasized in this respect is the fact that all teachers -regardless of their goal orientations- perceived having high scores would be a source of motivation. For example, T9 explained that they "felt that [the teacher's] efforts were rewarded when students scored high in the exams". Similarly, T8 noted "the high scores students get from exams indicate that they learned the course content and those who scored lower points are reminded that they need to study harder to make up for the content they did not know well enough".

In relation to being the best in academic success, teachers with L-M-P-GO orientations noted the importance of emphasizing the need to be the best. The rationale for this perception was that such emphasis could enable students to go beyond their capacity, and motivate students to exert further efforts in learning. It was also considered as an indicator of being a good teacher. Teachers with L-M-GO orientations, on the other hand, underlined the need to not emphasize being the best. Their rationale was that students should be evaluated individually and such emphasis can damage the relationship between teachers and students. In addition, students should be taught that having humanistic values was more important than academic success. For example, T5 explained they "believed the way is to appreciate students' efforts to do their best regardless of the outcome. Each student is born with different skills and characteristics".

As for in-class comparisons and highlighting model students, teachers with L-M-P-GO orientations considered in-class comparisons and highlighting model students to be important. Their rationale was that it was a source of motivation, allowed appreciation from others, and served as a tool for other students to explore their potential. Teachers with L-M-GO orientations, on the other hand, underlined that such comparisons should not be made. Their rationale was that comparisons decrease the connection between students, negatively affect motivation, disturb other students, ignore individual differences, and disrupt establishing an equal distance between the teacher and each student. This was also considered to prevent individual assessment as well as students' realization of their potential.
For example, T5 noted that they "witnessed the emergence of negative emotions many times [as a result of comparisons]" and $\mathrm{T} 1$ commented that they "thought [comparisons] negatively impact on the relationships among students which, permanently, could cause them to look for motivation in wrong places throughout their lives". The analysis of this dimension clearly indicates that there was a difference between teachers with different goal orientations. These statements are in line with the dimension of being the best in academic success which was covered above. In relation to this, T5 reported they "had model students in their classroom; however, [they] did not think that it would be right to highlight those students in the classroom. [They] tried to appreciate each and every one of my students and show [their] love to them".

\section{2.d. Making mistakes and supporting efforts}

The analysis of Table 12 suggests that all teachers associated making mistakes with positive meanings. Teachers considered making mistakes as proof of students trying to complete the given task, a tool for identifying the problem and providing feedback, and a means that show the necessity to use various teaching methods as well as a guide that directs learning processes. The meanings teachers attributed to making mistakes also included; enablers of learning and development, and guides for finding the right answer in a fast way. For example, T1 explained that "mistakes indicate that students are trying" and T2 stated "each mistake is an opportunity. It allows [students] to reach the right answer". Similarly, T3 noted that if students make mistakes then "there was a need to re-consider teaching methods".

In relation to supporting student efforts, teachers reported that they followed various practices such as rewarding students, increasing their intrinsic motivation, getting them to like the lesson, doing student-centred activities, allowing students to experience the sensation of success, and trying different methods and techniques. For example, T1 underlined that they "tried to reward students when they make an effort" and $\mathrm{T} 2$ stated they "tried to get students to like the lesson ... [they] tried to make connections between the lesson and real life, talked about students' interest areas, and used activities that would attract students' attention". Some of the teachers with L-M-PGO orientations reported that they would articulate mistakes to support students' efforts. Those teachers also reported that they would get students to ask for help from their more knowledgeable peers, get them to dream, and talk about the advantages of earning money. For example, T9 stated that they "would get students to dream about the future and frequently mention the advantages of earning money". The teachers were also asked about what sort of expressions they used to support student efforts. The answers included:

\section{T1: Let's not forget our goals!}

T2: Do your best, every answer you give does not have to be correct; I want to see your effort.

T5: I love you very much!

T6: Let's fulfil our responsibilities.

T9: If your parents are fulfilling their duties as parents then you have to fulfil your duties as a student. 


\begin{tabular}{|c|c|c|}
\hline \multicolumn{3}{|c|}{ Importance of scoring high in the exams } \\
\hline Orientation & Teacher & Student \\
\hline \multirow{2}{*}{$\begin{array}{l}\text { L-M-GO } \\
\text { L-M-P-GO }\end{array}$} & A tool for teachers to check and evaluate themselves & Source of motivation \\
\hline & Source of happiness & Source of happiness \\
\hline \multirow{3}{*}{ L-M-P-GO } & $\begin{array}{l}\text { Proof of studying harder for those who are less } \\
\text { successful }\end{array}$ & Source of motivation for other students \\
\hline & Proof of having taught the course content well & Proof of students having learned the course content \\
\hline & \multicolumn{2}{|c|}{ Emphasis on being the best in academic success } \\
\hline \multirow{4}{*}{ L-M-P-GO } & \multirow{4}{*}{ Being the best should be emphasized because... } & It is a tool for students to go beyond their capacity. \\
\hline & & It motivates all students. \\
\hline & & It is a tool of exerting efforts. \\
\hline & & It is a proof of being a good teacher. \\
\hline \multirow{5}{*}{ L-M-GO } & \multirow{4}{*}{ Attention should be paid to exerting effort because... } & It is important to support students. \\
\hline & & $\begin{array}{l}\text { Liking only the successful students is a wrong teacher behaviour } \\
\text { (liking students unconditionally) }\end{array}$ \\
\hline & & Showing students themselves \\
\hline & & People who have humanistic values are successful. \\
\hline & \multicolumn{2}{|c|}{ In-class comparisons- highlighting model students } \\
\hline L-M-GO & $\begin{array}{l}\text { Comparisons should not be made and model students } \\
\text { should not be highlighted in the classroom because... }\end{array}$ & $\begin{array}{l}\text { It decreases the connection between students. } \\
\text { It negatively affects motivation (unsuccessful students or students } \\
\text { who try to become the best). } \\
\text { Other students become uncomfortable. } \\
\text { It ignores individual differences. } \\
\text { It prevents individual assessment. } \\
\text { It prevents students from realizing their potential. } \\
\text { It prevents the connection between teachers and students being } \\
\text { equal for each student. }\end{array}$ \\
\hline \multirow{3}{*}{ L-M-P-GO } & \multirow{3}{*}{$\begin{array}{l}\text { Model students should be highlighted in the classroom } \\
\text { because... }\end{array}$} & It increases motivation. \\
\hline & & It is appreciated in the environment. \\
\hline & & It enables other students who explore their potential. \\
\hline
\end{tabular}

Table 11: Teachers' practices on comparing students in the classroom

\begin{tabular}{|c|c|}
\hline Orientation & Making mistakes \\
\hline \multirow{8}{*}{$\begin{array}{l}\text { L-M-GO } \\
\text { L-M-P-GO }\end{array}$} & Proof of trying to do \\
\hline & A tool for identifying the problem \\
\hline & Guiding the learning process \\
\hline & Supportive feedback to mistakes \\
\hline & The need to utilize various methods \\
\hline & Enabling learning and development \\
\hline & Getting students to find out the right answer \\
\hline & Supporting efforts \\
\hline \multirow{8}{*}{$\begin{array}{l}\text { L-M-GO } \\
\text { L-M-P-GO }\end{array}$} & Verbal support \\
\hline & Giving rewards \\
\hline & Increasing intrinsic motivation \\
\hline & Getting students to like the lesson \\
\hline & Student-centred activities \\
\hline & Allowing the sensation of success \\
\hline & Self-paced development \\
\hline & Various methods and techniques \\
\hline \multirow{4}{*}{ L-M-P-GO } & Articulating student mistakes \\
\hline & Asking help from a more knowledgeable peer \\
\hline & Getting students to dream \\
\hline & Talking about the advantages of earning money \\
\hline
\end{tabular}

Table 12: Teacher practices with regards to making mistakes and supporting efforts 


\section{2.e. Competition in the classroom}

Analysis of Table 13 suggests there were a mix of positive and negative perceptions with regards to competition in the classroom. Few teachers indicated that ensuring fair competition was impossible and others considered competition to be an obstacle. Nevertheless, they also added that students needed to enter competition since the competition was an indispensable part of life. In relation to this, T2 stated they "perceived competition as a barrier that prevents students from developing positive relationships with their selves, peers, teachers, and families. However, the culture of competition has become a natural part of life and it is difficult to isolate the classroom from this". Some teachers explained that rankings did not matter and competition was not a source of motivation. What was important for those teachers was that students were in a competition with themselves. For example, T1 noted they "tried not to create a competitive environment for students who could develop negative emotions in a competitive environment". Furthermore, few teachers mentioned that team games should be preferred to competitions in the classroom. Teachers with L-M-P-GO orientations, on the other hand, had positive perceptions of having a competition in the classroom. According to those teachers, competitions increase students' hunger for learning, are tools for instigating students with low levels, and tools that activate students. T9 remarked that they "organized competitions to increase students' motivation in certain topics, or fire low level students up". Similarly, $\mathrm{T} 7$ explained that "the feeling of competition allows people to become more open to learning. Students become more motivated".

\begin{tabular}{|c|c|c|}
\hline \multicolumn{3}{|c|}{ Competition in the classroom } \\
\hline \multirow{7}{*}{ L-M-GO } & \multirow{2}{*}{ Positive } & Competition is an obstacle but also an indispensable part of our lives \\
\hline & & Making students compete with their own development \\
\hline & \multirow{5}{*}{ Negative } & Unimportance of ranking \\
\hline & & Creation of negative feelings \\
\hline & & Impossibility of a fair competition \\
\hline & & Preferring team games \\
\hline & & Not being a source of motivation for all students \\
\hline \multirow{4}{*}{ L-M-P-GO } & \multirow{4}{*}{ Positive } & Increasing the hunger for learning \\
\hline & & A tool for instigating students with low levels \\
\hline & & Paying attention to use it at a necessary amount \\
\hline & & A tool that activates students \\
\hline
\end{tabular}

Table 13: Teachers practices with regards to competition in the classroom

\section{DISCUSSION}

The results of the study showed that participating teachers defined themselves to be student-centred. They used terms such as "student-teacher" and "being a student forever" when describing themselves. The analysis of the data suggested that there were many reasons for teachers to be involved in continuous learning. Those included; individual, classroom, school, and student-related reasons. Regardless of their goal orientation, teachers expressed that they did not mind the learning journey and underlined they were happy and satisfied for gaining new experiences and being with students as a result of their journey. Learning-centred teachers try to improve their development in both formal and informal educational contexts. Such activities can develop teachers' knowledge and skills (Lohman, 2006) and, at the same time, are related to teachers' goal orientations (Kunst, van Woerkom and Poell, 2018). Teachers who defined themselves as having L-M-P-GO orientations explained that they experienced negative emotions during their learning journeys. They stated that not knowing resulted in situations where they felt "shy" and "upset" because of "the anxiety of having too many things to learn". There were differences in the negative ideas and emotions teachers experienced because of "not knowing". Achievement goal orientation plays an important role in predicting various emotions relating to success. Studies on this topic were conducted with students, school teachers, and university instructors (Rinas et al., 2020). For example, the study Rinas et al. (2020) conducted with university lecturers and studies of Janke and Dickhauser (2019) and Wang et al. (2017) which were conducted with teachers investigated the relationship between educators' emotions and their goal orientations. The results showed that mastery/learning goal orientation was positively correlated with enjoyment. Additionally, Janke and Dickhauser (2019) found that performance-approach goal orientation was negatively correlated with anxiety and shame while performance-avoidance goal orientation was positively correlated with those two emotions. The external standards that teachers with performance goal orientations set for themselves may cause such negative emotions.

It is understood from the literature that individuals who had mastery/learning goal orientations focus on developing their skills (Butler, 2007, 2012; Roeser, Midgely and Urdan, 1997). All teachers in the present study described themselves as making efforts in their journey towards learning. This finding supports the idea that teachers with performance goal orientations can also have positive perceptions towards learning. Related literature indicated that individuals with performance goal orientations had positive perceptions of selfconcepts, attitudes, value given to academic studies, making an effort, and meta-cognitive skills (Elliot and McGregor, 1999; Midgley, Arunkumar, and Urdan, 1996; Pajares, Britner, and Valiante, 2000). The meta-analysis study conducted by Payne, Youngcourt, and Beaubien (2007) revealed that there was a low positive correlation between learning and performance 
goal orientations. Similarly, the study conducted by Retelsdorf et al. (2010) found that while mastery/learning goal orientation was positively correlated with interest in teaching and classroom teaching activities, ability approach goal orientation (among performance-oriented approaches) had a neutral effect and was not a predictor of interest in teaching and classroom teaching activities. Kunst, Woerkom and Poell's (2018) study conducted with teachers revealed that teachers' participation in professional development activities was higher among teachers with high mastery/learning goal orientation, and teachers with high performance orientation and low performance-avoidance orientations were also high. This situation indicates that not only mastery goal oriented teachers but also teachers with various goal orientation combinations have high levels of eagerness for learning and development. Therefore, it can be interpreted that learning for professional development in today's world has become a necessity rather than an option.

The analysis of relationships between teachers who want to develop professionally and their students highlight the importance of this relationship for the success of teaching practices. Previous research concluded that the positive relationship between teachers and students positively affects student participation and academic success, and provides students with socio-emotional support (Butler, 2012; Butler and Shibaz, 2014; Davis, 2003; Roorda, Koomen, Spilt, and Oort, 2011). Teachers who are effective communicators can nurture friendship with students, which positively affect students' perceptions of learning environments (Haralambos and Holborn, 2008). Related research also indicated that teachers' orientations in relation to building social relationships with students were positively correlated with using masteryoriented teaching techniques (Butler, 2012; Wang et al., 2017) and teaching-related enjoyment (Wang et al., 2017). It was observed that there were teachers -regardless of their goal orientation- who wanted to establish good relationships with students. A noteworthy aspect, however, is that male teachers in the present study who taught in high schools underlined that they wanted to have a relationship with students which was based on respect. This finding can be discussed from various perspectives. It is possible that as they become teenagers, students become more independent and start to focus more on their peers (Roorda, Koomen, Spilt, and Oort, 2011; Hargreaves, 2000) resulting in a more respect-oriented relationship between teachers and students. From another point of view, the gender of the teacher might be the reason for male teachers' focus on respect-oriented relationship. Alternatively, ethnic and cultural identity roles and cultural factors might have an effect on teachers' goal orientations. In fact, recent research suggested that further research should be carried out on goal orientations and gender (Urdan and Kaplan, 2020).

The results indicated that there were instances where teachers avoided work even though they had mastery/learning goal orientations. Those situations included when teachers were given redundant tasks to sow off, compulsory group work where having the high number of participants was the main priority, tasks that were not rewarded, and compulsory projects. A picture where teachers avoid making an effort or try to complete a given task as soon as possible was depicted in relation to tasks given on a compulsory basis. Teachers perceived that neither teachers nor students benefited from such tasks. Work-avoidance is classified as a different goal orientation. The analysis of related literature suggests that work-avoidance goal orientation is associated with abstaining from making an effort, avoiding difficult tasks, having negative attitudes towards given tasks, limited cognitive participation, and boredom (Dowson and McInerney, 2001; Seifert and O'Keefe, 2001). In fact, the analysis of teacher responses suggests that they were bored and avoided tasks which they perceived to be meaningless or which were given as compulsory tasks. It is indisputable that project work is quite advantageous for both students and teachers when it is administered in line with the project goals. However, teachers in this study were found to abstain from participating in projects. In fact, one of the participants clearly articulated their negative feelings towards the word "project" by stating that they did not like the word at all. The review of literature suggests that workavoidance goal orientation is associated with a lack of perceived meaning and boredom (Dowson and McInerney, 2000; Jarvis and Seifert, 2002; Seifert and O'Keefe, 2001). In this sense, the goals aimed to be achieved are not realized when teachers are asked to undertake tasks they do not like. Whatever task that teachers are given should be meaningful to them and support should be provided to help them undertake the given task. Dickhäuser et al (2020) found that teachers' goal orientations are operationalized as positive feedback culture has a positive correlation with learning goal orientation. Similarly, Janke and Dickhäuser's (2019) research revealed that teachers' learning goal orientations were positively correlated with the school environment where autonomy support was provided or a cooperative climate was present.

One of the practices that the positive feedback culture allows is the feedback given to teachers' successes and/or failures. All participating teachers in the present study wanted their successes to be known and appreciated by others and considered it as a source of motivation. In other words, there was not a much difference between teachers who possessed different goal orientations in terms of wanting their successes being heard by others and wanting to have positive perceptions in their social environment. This suggests that having a positive perception in their social environment is important for teachers. Others knowing about their successes was perceived by teachers as allowing them to be branded as "model teachers", increase their self-efficacy and self-respect, and increase the trust and respect others had in teachers. Having such social needs met is, in a way, a reward. Research has found that such rewards motivate teachers at work, encourage them to work and love their profession, and reveal the difference between those who work hard and those who are lazy (Yildırım, 2008). Research has also found that teachers wanted their successes to be appreciated and rewarded by the institutions in which they worked (Çelebi, Vuranok and Turgut, 2015). As a result, teachers experience enjoyment, satisfaction, and pride. It has been observed that teachers want a school system where they are supported and rewarded. If such needs are not met, teachers become more inclined to exert work-avoidance behaviour. Additionally, regardless of their goal orientations, 
all teachers, who wanted their successes to be known by others, were uncomfortable with the idea of their failures being known by others. This suggests successes or failures are not adequately addressed. These results provide further support to the ideathat individuals can possess multiple goal orientations (Hidi and Harackiewicz, 2002), and, for example, while on one hand side they want to increase their knowledge and skills on the other hand they do not want to lose face and, thus avoid actions which have a potential to make them look bad (Gordon, Dembo and Hecover, 2007). From another point of view, thanks to the adaptive effects of goal orientations, individuals who possess different goal orientations may reach the same result by following different strategies. In other words, while mastery/learning goal orientations support individuals through interest, effort and so on, performance goal orientation support individuals through the wish to become successful, both of which render individuals adaptive (Barron and Harackiewicz, 2001).

Achievement goal theory provides a rich framework that allows the explanation of the relationship between teachers' beliefs and classroom structures (Pintrich and Schunk, 2002). The results on taking individual differences into account and classroom practices category suggested that all teachers regardless of their goal orientations- classified student levels and taught crowded classrooms at a level that was appropriate for an average student. Teachers with L-M-P-GO orientations expressed that they gave extra homework or directed students towards peer learning in cases where learning did not occur. Teachers with L-M-GO orientations, on the other hand, preferred to support learning with extra-curricular activities. If the classroom was not crowded, those teachers also reported that they tried to support students with one-to-one learning. Various characteristics of mastery-structured contexts have been highlighted in the literature; giving students a range of different and authentic tasks, focus on learning and development, creating heterogeneous student groups in terms of knowledge and skills, working with small groups, development-oriented evaluation, and flexible timing. In contrast, performancestructured contexts were characterized as lacking the variety of tasks given to students, students having the tendency to show their knowledge and skills to others, homogeneous student groups, normative assessment, and inflexible timing. When educational contexts are both mastery and performanceoriented, then classroom structures can also be mastery and performance-oriented (Linnenbrink, 2005). While on one hand, the Turkish education system underlines the importance of personal development on the other hand it asks that teaching processes have accountability mechanisms through the use of standardized tests. This, as a result, can create a mix of context combinations that are observed in the classrooms. The analysis of teachers' reported classroom practices suggests that teachers used a range of different methods, techniques, and strategies to support learning. Teachers' practices can be both performance and mastery oriented. That is to say, teachers with mastery/learning goal orientations do not always create mastery structured classrooms. Evaluating this within the context of the Turkey indicates that while the education sytem highlights the importance of development on one hand side, it expects accountability for the learning processes by following standardized tests on the other. Therefore, this can result in combined contexts within the classrooms. The analysis of teachers' classroom activities showed that all teachers (regardless of goal orientations) followed different methods, techniques, and strategies in the classroom.

It has been observed that teachers' practices were similar with regards to making mistakes and supporting efforts. All teachers perceived that making mistakes was a process that supported learning. However, responses provided by a few of the teachers with L-M-P-GO orientations were noteworthy to remark. In fact, teachers with such goal orientations -as explained abovecould not sufficiently undertake activities which take individual differences into account when their classrooms were crowded. To support students' efforts, such teachers reported that they explicitly told students about their mistakes, made students to ask for help from more knowledgeable peers, asked students to dream, and talked with students about the advantages of earning money. These bring up the following questions: Is explicitly telling students about their mistakes a supportive feedback? Or does not asking students to get help from more knowledgeable peers increase competition? It was clear that teachers grouped students based on academic success. Since when has learning course content become equal to earning money? Does such discourse really serve the purposes of education which aim to nurture individuals? Should such discourse be used as a tool to motivate students? It is also worth noting teachers also had performance goal orientations. Performance goal orientation prioritizes showing successes to others and becoming better than others (Butler, 2007; Nitsche et al., 2011). And this might result in teachers with performance goal orientations to support such teaching practices.

The analysis of expressions teachers used to support student efforts showed that those statements were superficial and did not include individual solution suggestions. Making mistakes in the classroom and supporting students' efforts is an important part of teaching-learning processes and provide valuable clues to evaluate student learning. Additionally, the feedback provided to students determines the quality of teaching-learning processes. To enable student learning, teachers should provide nutritious feedback to students. None of the general comments made by the participating teachers seemed to provide students with information that would help them increase their performance (Brookhart, 1997).

In the study, participating teachers' perceptions of exams supported the educational contexts dimension. All teachers considered that exams were not sufficient to evaluate students. They, nevertheless, added that exams were still an important part of the evaluation. In relation to sharing exam results in front of students, while teachers with L-M-GO orientations advocated the idea that exam results should not be publicly announced in the classroom, teachers with L-M-P-GO orientations supported the idea that exams can be publicly announced. Teachers in the latter group considered that announcing the most successful students to the whole class not only increased student motivation but also provided teachers with a mechanism to check and show students that the teacher has accurately administered the evaluation criteria. This group of teachers had the tendency to create a classroom environment 
where what others thought about an individual matter. Related research found that teachers with such orientations take skill differences among students into account, focus on high achievement and follow practices that enable others to observe the achievements (Butler, 2007, 2012; Dickhauser, Butler and Toenjes, 2007). Findings in the category of in-class comparisons also supported results in relation to teachers' exam practices. While teachers with L-M-GO orientation did not approve practices that emphasize being the best, teachers with L-M-P-GO orientations underlined the importance of emphasizing being the best. The former group did not perceive this situation to support learning. However, the perceptions of the latter group were the opposite. Perception differences based on goal orientations included findings that supported each other. While practices such as emphasizing being the best in the classroom or comparing students with one another create a positive effect for students who score high, less successful students are negatively affected by such practices (Patrick, Kaplan and Ryan, 2011). Teachers should take such issues into account when planning teaching activities. How can teachers emphasize being the best when they claim that they focus on personal development? To what extend do they really value personal development? It is clear that teachers with L-M-P-GO orientations undertook activities that were not consistent.

At the same time, emphasis on being the best in the class points to the competition. In the present research, teachers with L-MGO orientations were indecisive about competition in the classroom and had both positive and negative perceptions on this matter. Teachers with L-M-P-GO orientations, on the other hand, had positive perceptions of competition in classrooms. Indecisive teachers reported that while they did not think that a fair competition possible, students should enter competition since it was an indispensable part of life. Those with negative perceptions considered competition to impede learning and those with positive perceptions treated it as a source of motivation. In fact, the researcher of this study asked participants about the competition without specifying the type of competition (i.e. individual or group). Nevertheless, all participants perceived competition as group competition and gave answers considering exams. It is possible that all teachers attached the same meaning to the term "competition" since they were also brought up and encultured in the same education system. Exams play a central role in the Turkish education system. Exams indicate that there are rankings where the "good" and "bad" are on the radar. And this is reflected as competition in classroom environments. Performance-oriented behaviours and the outcomes of such behaviours can in fact motivate students and teachers towards success in classrooms where normative assessment and social comparison are strongly emphasized (Urdan and Kaplan, 2020), which might be a potential reason why teachers were indecisive.

\section{CONCLUSION}

The results of the present study were based on teachers' perceptions. Findings, in general, suggested that along with changes in the dynamics of education systems, behavioural patterns in relation to goal-orientations become more interwoven. Although teachers considered their classroom practices to be sufficient for the student, further research can be carried out to identify how students perceive their teachers' practices. Future research can also investigate the practices of teachers who possess different goal orientations so that more detailed information can be reached in relation to this topic. The present study adopted a qualitative approach. The sample size in qualitative studies depends on the aim of the study and such studies can be conducted with a lower number of participants in order to gain an in-depth understanding of the research topic (Patton, 2002). As such, the present study was conducted with a small number of participants in an effort to gain an in-depth information regarding teachers' goal orientations. As can be seen in the results, insights into participating teachers' behavioral patterns were gained at the end of the research process. Nevertheless, future research can focus on recruiting a higher number of participants in order to understand behavioral patterns of the teacher with different goal orientations. Such research can allow the re-evaluation of the generalized information on goal orientations.

\section{REFERENCES}

Ames, C. (1992) 'Classrooms: Goals, structures, and student motivation', Journal of Educational Psychology, Vol. 84, No. 3, pp. 261-271. https://doi.org/10.1037/0022-0663.84.3.261

Barron, K. E. and Harackiewicz, J. M. (2001) 'Achievement goals and optimal motivation: Testing multiple goal models', Journal of Personality and Social Psychology, Vol. 80, No. 5, pp. 706-722. https://doi.org/10.1037/0022-3514.80.5.706

Borko, H. (2004) 'Professional development and teacher learning: Mapping the terrain. Educational Researcher, Vol. 33, No. 8, pp. 3-15. https://doi.org/10.3102/0013189X033008003

Brookhart, S. M. (1997) 'A theoretical framework for the role of classroom assessment in motivating student effort and achievement', Applied Measurement in Education, Vol. 10, No. 2, pp. 161-180. https://doi.org/10.1207/ s15324818ame1002_4
Butler, R. (2007) 'Teachers' achievement goal orientations and associations with teachers' help seeking: Examination of a novel approach to teacher motivation', Journal of Educational Psychology, Vol. 99, No. 2, pp. 241-252. http:// dx.doi.org/10.1037/0022-0663.99.2.241

Butler, R. (2012) 'Striving to connect: Extending an achievement goal approach to teacher motivation to include relational goals for teaching', Journal of Educational Psychology, Vol. 104, No. 3, pp. 726-742. http://dx.doi.org/10.1037/a0028613

Butler, R. and Shibaz, L. (2014) 'Striving to connect and striving to learn: Influences of relational and mastery goals for teaching on teacher behaviors and student interest and help seeking', International Journal of Educational Research, Vol. 65, pp 41-53. https://doi.org/10.1016/j. ijer.2013.09.006 
Çelebi, N., Vuranok, T. T. and Turgut, I. H. (2015) 'The perceptions of primary and secondary school teachers on reward system', Mehmet Akif Ersoy University Journal of Education Faculty, [in Turkish], Vol. 1, No. 34, pp. 75-104.

Daumiller, M., Dickhäuser, O. and Dresel, M. (2019) 'University instructors' achievement goals for teaching', Journal of Educational Psychology, Vol. 111, No. 1, pp. 131-148. https:// doi.org/10.1037/edu0000271

Davis, H. A. (2003) 'Conceptualizing the role and influence of student-teacher relationships on children's social and cognitive development', Educational Psychologist, Vol. 38, No. 4, pp. 207-234. https://doi.org/10.1207/ $\underline{\text { S15326985EP3804_2 }}$

Dickhauser, O., Butler, R. and Toenjes, B. (2007) 'That shows I can't do it: Goals and attitudes to help seeking among preservice teachers', Zeitschrift fur Entwicklungspsychologie und Paedagogische Psychologie, Vol. 39, pp. 120-126. https://doi. org/10.1026/0049-8637.39.3.120

Dickhäuser, O., Janke, S., Daumiller, M. and Dresel, M. (2020) 'Motivational school climate and teachers' achievement goal orientations: A hierarchical approach', British Journal of Educational Psychology, Vol. 91, No. 1, pp. 391-408. https:// doi.org/10.1111/bjep.12370

Dowson, M. and McInerney, D. (2001) 'Psychological parameters of students' social and work avoidance goals: A qualitative investigation', Journal of Educational Psychology, Vol. 93, No. 1, pp. 35-42. https://doi.org/10.1037/0022-0663.93.1.35

Dweck, C. S. (1986) 'Motivational processes affecting learning', American Psychologist, Vol. 41, No. 10, pp. 1040-1048. http://dx.doi.org/10.1037/0003-066X.41.10.1040

Dweck, C. S. (1990) 'Self-theories and goals: Their role in motivation, personality, and development', in Dienstbier R. A. (ed.), Nebraska symposium on motivation (Vol. 38, pp. 199-235), Lincoln: University of Nebraksa Press.

Eccles, J. S. and Roeser, R. W. (2011) 'Schools as developmental contexts during adolescence', Journal of Research on Adolescence, Vol. 21, No. 1, pp. 225-241. http://dx.doi. org/10.1111/j.1532-7795.2010.00725.x

Elliot, A. J. and Harackiewicz, J. M. (1996) 'Approach and avoiding achievement goals and intrinsic motivation: A meditational analysis', Journal of Personality and Social Psychology, Vol. 70, No. 3, pp. 461-475. http://dx.doi.org/10.1037/00223514.70.3.461

Elliot, A. J. and McGregor, H. A. (1999) 'Test anxiety and the hierarchical model of approach and avoidance achievement motivation', Journal of Personality and Social Psychology, Vol. 76, No. 4, pp. 628-644. https://doi.org/10.1037/0022$\underline{3514.76 .4 .628}$

Elliot, A. J. and McGregor, H. A. (2001) 'A 2×2 achievement goal framework', Journal of Personality and Social Psychology, Vol. 80, No. 3, pp. 501-519. http://dx.doi.org/10.1037/0022$\underline{3514.80 .3 .501}$

Elliot, A., Murayama, K. and Pekrun, R. (2011) 'A 3 x 2 achievement goal model', Journal of Educational Psychology, Vol. 103, No. 3, pp. 632-648. http://dx.doi.org/10.1037/a0023952

Gordon, S. C., Dembo, M. H. and Hocevar, D. (2007) 'Do teachers' own learning behaviors influence their classroom goal orientation and control ideology?', Teaching and Teacher Education, Vol. 23, No. 1, pp. 36-46. https://doi.org/10.1016/j. tate.2004.08.002
Grant, H. and Dweck, C. (2003) 'Clarifying achievement goals and their impact', Journal of Personality and Social Psychology, Vol. 85, No. 3, pp. 541-553. https://doi.org/10.1037/0022-3514.85.3.541

Hargreaves, A. (2000) 'Mixed emotions: Teachers' perceptions of their interactions with students', Teaching and Teacher Education, Vol. 16, No. 8, pp. 811-826. https://doi.org/10.1016/S0742$\underline{051 X(00) 00028-7}$

Hidi, S. and Harackiewicz, J. M. (2002) 'Motivating the academically unmotivated: A critical issue for the 21st century', Review of Educational Research, Vol. 70, No. 2, pp. 151-179. https://doi. org/10.3102/00346543070002151

Janke, S. and Dickhauser, O. (2019) 'A neglected tenet of achievement goal theory: Associations between life aspirations and achievement goal orientations', Personality and Individual Differences, Vol. 142, pp. 90-99. https://doi.org/10.1016/j.paid.2019.01.038

Janssen, O. and Prins, J. (2007) 'Goal orientations and the seeking of different types of feedback information', Journal of Occupational and Organizational Psychology, Vol. 80, No. 2, pp. 235-249. https://doi.org/10.1348/096317906X103410

Jarvis, S. and Seifert, T. (2002) 'Work avoidance as a manifestation of hostility, helplessness, and boredom', Alberta Journal of Educational Research, Vol. 48, No. 2, pp. 174-187.

Karabenick S. A. (2004) 'Perceived achievement goal structure and college student help seeking', Journal of Educational Psychology, Vol. 96, No. 3, pp. 569-581. https://doi.org/10.1037/0022$\underline{0663.96 .3 .569}$

King, R. B. and McInerney, D. M. (2014) 'Culture's consequences on student motivation: Capturing cross-cultural universality and variability through personal investment theory', Educational Psychologist, Vol. 49, No. 3, 175-198. https://doi.org/10.1080/00 $\underline{461520.2014 .926813}$

Kucsera, J. V., Roberts, R., Walls, S., Walker, J. and Svinicki, M. (2011) 'Goal orientation towards teaching (GOTT) scale', Teachers and Teaching, Vol. 17, No. 5, pp. 597-610. https://doi.org/10.1080/13 $\underline{540602.2011 .602212}$

Kunst, E. M., van Woerkom, M. and Poell, R. F. (2018) 'Teachers' goal orientation profiles and participation in professional development activities', Vocations and Learning, Vol. 11, No. 1, pp. 91-111. https://doi.org/10.1007/s12186-017-9182-y

Levy, I., Kaplan, A. and Patrick, H. (2004) 'Early Adolescents' achievement goals, social status, and attitudes towards cooperation with peers', Social Psychology of Education, Vol. 7, pp. 127-159. https://doi.org/10.1023/B:SPOE.0000018547.08294.b6

Linnenbrink, E. A. (2005) 'The Dilemma of Performance-Approach Goals: The Use of Multiple Goal Contexts to Promote Students' Motivation and Learning', Journal of Educational Psychology, Vol. 97, No. 2, pp. 197-213. https://doi.org/10.1037/0022$\underline{0663.97 .2 .197}$

Lohman, M. C. (2006) 'Factors influencing teachers' engagement in informallearningactivities',Journal of Workplace Learning, Vol.18, No. 3, pp. 141-156. https://doi.org/10.1108/13665620610654577

Meece, J. L., Anderman, E. M. and Anderman, L. H. (2006) 'Classroom goal structure, student motivation, and academic achievement', Annual Review of Psychology, Vol. 57, pp. 487-503. https://doi. org/10.1146/annurev.psych.56.091103.070258

Midgley, C, Arunkumar, R. and Urdan, T. (1996) 'If I don't do well tomorrow, there's a reason: Predictors of adolescents' use of academic self-handicapping behavior', Journal of Educational Psychology, Vol. 88, No. 3 pp. 423-434. https://doi. org/10.1037/0022-0663.88.3.423 
Midgely, C., Kaplan, A. and Middleton, M. (2001) 'Performanceapproach goals: good for what, for whom, under what circumstances, and at what cost?', Journal of Educational Psychology, Vol. 93, No. 1, pp. 77-86. https://doi. org $/ 10.1037 / / 0022-0663.93 .1 .77$

Miles, M. B. and Huberman, A. M. and Saldaña, J. (2014) Qualitative data analysis: A methods sourcebook, 3rd edition, Thousand Oaks, CA: Sage.

Murayama, K. and Elliot, A. J. (2009) 'The joint influence of personal achievement goals and classroom goal structures on achievementrelated outcomes', Journal of Educational Psychology, Vol. 101, No. 2, pp. 432-447. http://dx.doi.org/10.1037/a0014221

Nicholls, J. G. (1984) 'Achievement motivation: conceptions of ability, subjective experience, task choice, and performance', Psychological Review, Vol. 91, No. 3, pp. 328-346. http://dx.doi. org/10.1037/0033-295X.91.3.328

Nitsche, S., Dickhäuser, O., Fasching, M. S. and Dresel, M. (2011) 'Rethinking teachers' goal orientations: Conceptual and methodological enhancements', Learning and Instruction, Vol. 21, No. 4, pp. 574-586. http://dx.doi.org/10.1016/j. learninstruc.2010.12

Pajares, F., Britner, S. and Valiante, G. (2000) 'Relation between achievement goals and self-beliefs of middle school students in writing and science', Contemporary Educational Psychology, Vol 25, No. 4, pp. 406-422. https://doi.org/10.1006/ceps.1999.1027

Patrick, H., Anderman, L. H., Ryan, A. M., Edelin, K. C. and Midgley, C. (2001) 'Teachers' Communication of goal orientations in four fifth-grade classrooms', The Elementary School Journal, Vol. 102, No. 1, pp. 35-58. http://dx.doi.org/10.1086/499692

Patrick, H., Kaplan, A. and Ryan, A. M. (2011) 'Positive classroom motivational environments: Convergence between mastery goal structure and classroom social climate. Journal of Educational Psychology, Vol. 103, No. 2, pp. 367-382. http://dx.doi. org/10.1037/a0023311

Patton. M. Q. (2002) Qualitative research \& evaluation methods, 3rd edition, Thousand Oaks, CA: Sage.

Payne, S. C., Youngcourt, S. S. and Beaubien, J. M. (2007) 'A metaanalytic examination of the goal orientation nomological net', Journal of Applied Psychology, Vol. 92, No.1, pp. 128-150. http://dx.doi.org/10.1037/0021-9010.92.1.128

Pintrich, P. R. (2000) 'The role of goal orientation in self-regulated learning', in Boekaerts, M., Pintrich, P. R. and Zeidner, M. (ed.) Handbook of self-regulation (pp. 451-502), New York, NY: Academic Press.

Pintrich, P. R. and Schunk, D. H. (2002) Motivation in education: theory, research, and applications, 2nd edition, Englewood Cliffs, NJ: Prentice Hall.

Retelsdorf, J., Butler, R., Streblow, L. and Schiefele, U. (2010) 'Teachers' goal orientations for teaching: Associations with instructional practices, interest in teaching, and burnout', Learning and Instruction, Vol. 20, No. 1, pp. 30-46. https://doi. org/10.1016/j.learninstruc.2009.01.001
Rinas, R., Dresel, M., Hein, J., Janke, S., Dickhäuser, O. and Daumiller, M. (2020) 'Exploring university instructors' achievement goals and discrete emotions', Frontiers in Educational Psychology. Vol. 11, 1486. https://doi.org/10.3389/fpsyg.2020.01484

Roeser, R. W., Midgely, C. and Urdan, T. C. (1996) 'Perceptions of the school psychological environment and early adolescents' psychological and behavioral functioning in school: The mediating role of goals and belonging', Journal of Educational Psychology, Vol. 88, No. 3, pp. 408-422. https://doi. org/10.1037/0022-0663.88.3.408

Roorda, D. L., Koomen, H. M. Y., Spilt, J. L. and Oort, F. J. (2011) 'The influence of affective teacher-student relationships on students' school engagement and achievement: A meta-analytic approach', Review of Educational Research, Vol. 81, No. 4, pp. 493-529. https://doi.org/10.3102/0034654311421793

Seifert, T. and O'Keefe, B. (2001) 'The relationship of work avoidance and learning goals to perceived competence, externality and meaning', British Journal of Educational Psychology, Vol. 71, No. 1, pp. 81-92. https://doi.org/10.1348/000709901158406

Throndsen, I. and Turmo, A. (2012) 'Primary mathematics teachers' goal orientations and student achievement. Instructional Science, Vol. 41, No. 2, pp. 307-322. https://doi.org/10.1007/s11251-0129229-2

Urdan, T. and Kaplan, A. (2020) 'The origins, evolution, and future directions of achievement goal theory', Contemporary Educational Psychology, Vol. 61, Article 101862. https://doi. org/10.1016/j.cedpsych.2020.101862

Wang, H., Hall, N. C., Goetz, T. and Frenzel, A. C. (2017) 'Teachers' goal orientations: Effects on classroom goal structures and emotions', British Journal of Educational Psychology, Vol. 87, No. 1, pp. 90-107. https://doi.org/10.1111/bjep.12137

Wolters, C. A. and Daugherty, S. G (2007) 'Goal structures and teachers' sense of efficacy: Their relation and their association to teaching experience and academic level', Journal of Educational Psychology, Vol. 99, No. 1, pp. 181-193. https://doi. org/10.1037/0022-0663.99.1.181

Yıldırım, C. M. (2008) 'Primary school teachers' and administrators' views about rewarding teachers', Educational Administration: Theory and Practice, Vol. 14, No. 4, pp. 663-690.

Yıldızlı, H., Saban, A. and Baştuğ, M. (2016) 'Adaptation of goal orientations for teaching scale into Turkish', Elementary Education Online, [in Turkish], Vol. 15, No. 4, pp. 1254-1267. http://dx.doi.org/10.17051/io.2016.62664

Yildızlı, H. (2019) 'Structural relationships among teachers' goal orientations for teaching, self-efficacy, burnout, and attitudes towards teaching', Journal on Efficiency and Responsibility in Education and Science, Vol. 12, No. 4, pp. 111-125. http:// dx.doi.org/10.7160/eriesj.2019.120402

Yıldizlı, H. (2020) 'Classroom assessment practices and student goal orientations in mathematics classes', Journal of Qualitative Research in Education, Vol. 8, No. 1, pp. 294-323. http://dx.doi. org/10.14689/issn.2148-2624.1.8c.1s.13m 